Article

\title{
Performance Evaluation and Field Application of Porous Vegetation Concrete Made with By-Product Materials for Ecological Restoration Projects
}

\author{
Hwang-Hee Kim $^{1}$ and Chan-Gi Park ${ }^{2, *}$ \\ 1 Research Institute of Technology, Nature and Environment Co. Ltd, 116-28 Boheung-1Gil, Kongju 325-33, \\ Korea; hwanghekim@hanmail.net \\ 2 Department of Rural Construction Engineering, Koungju National University, 54 Daehak Street, \\ Yesan 340-702, Korea \\ * $\quad$ Correspondence: cgpark@kongju.ac.kr; Tel.: +82-41-330-1266; Fax: +82-41-330-1269
}

Academic Editor: Vincenzo Torretta

Received: 8 March 2016; Accepted: 18 March 2016; Published: 23 March 2016

\begin{abstract}
The purpose of this study was to evaluate the performance of porous vegetation concrete block made from blast furnace slag cement containing industrial by-products such as blast furnace slag aggregate and powder. The blocks were tested for void ratio, compressive strength and freeze-thaw resistance to determine the optimal mixing ratio for the porous vegetation block. An economic analysis of the mixing ratio showed that the economic efficiency increased when blast furnace slag aggregate and cement were used. Porous vegetation concrete blocks for river applications were designed and produced. Hydraulic safety, heavy metal elution and vegetation tests were completed after the blocks were applied in the field. The measured tractive force ranged between $7.0 \mathrm{~kg} / \mathrm{m}^{2}$ for fascine revetment (vegetation revetment) and $16.0 \mathrm{~kg} / \mathrm{m}^{2}$ for stone pitching (hard revetment), which ensured sufficient hydraulic stability in the field. Plant growth was measured after the porous vegetation concrete block was placed in the field. Seeds began to sprout one week after seeding; after six weeks, the plant length exceeded $300 \mathrm{~mm}$. The average coverage ratio reached as high as $90 \%$ after six weeks of vegetation. These results clearly indicated that the porous vegetation concrete block was suitable for environmental restoration projects.
\end{abstract}

Keywords: by-product materials; economic analysis; field application; hydraulic stability; laboratory test; latex polymer; porous vegetation concrete block

\section{Introduction}

Numerous studies of concretes have been reported for eco-restoration applications. Among these, porous vegetation concrete is of particular interest and has found practical applications as an eco-restoration material [1-8]. Porous vegetation concrete can be used as a river revetment. Plants can grow within the porous concrete because water, air and plant roots can freely pass through its continuous pores. Porous vegetation concrete can be completely covered by vegetation and it provides space for bio-reproduction [9-14]. Furthermore, by promoting the accumulation of sand, it can help regenerate nature [15]. Plants cannot generally grow on concrete because it does not provide space for rooting and sprouting, it has low water permeability and retentivity, and it provides no nutrients [2-10]. On the other hand, the void ratio of vegetation concrete allows plants to grow within it: filling of the pores with water and nutrients promotes plant growth [11-14]. A thin coating of soil on the surface of porous concrete can provide plants with sprouting space and prevents the evaporation of water, and serves as the initial source of fertilizer after sprouting. Porous vegetation concrete is overlaid with a thin layer of surface soil [11-15]. The constitutional requirements for vegetation concrete are an ability 
to allow plants to grow within the concrete and sufficient mechanical properties to act as a concrete frame [11-13]. Additionally, for plant growth, the four conditions of sunlight, space for growth, air and soil are required [15]. The soil should have sufficient water retentivity and permeability, and should contain the necessary water and nutrients. Porous vegetation concrete is usually made by reducing the volume of small aggregates conventionally used in ordinary concrete, which increases the number of pores. The unit amount of cement is usually $300-400 \mathrm{~kg} / \mathrm{m}^{3}$ and the optimum water/cement ratio is $30 \%-40 \%$ [11-13]. If the water/cement ratio is higher than this, the cement paste becomes too fluid and flows away; too low a ratio makes it difficult to pack in a mold. The optimum mixing ratio for porous concrete is established using indoor testing [11-13]. The characteristic feature of porous vegetation concrete block is the coexistence of continuous and independent pore structures [11-13]. To date, porous vegetation concrete studies have focused on promoting the penetration of plant roots into the porous concrete and generating microbes and other small organisms in the soil by adding filler to the soil, using water-retentive materials and adding fertilizer and alkaline buffering materials [15]. Many studies have tried to maximize recycling by using industrial byproducts [8-10]. The bottom ash from thermoelectric power plants, which is usually discarded, was used for porous vegetation concrete. Its mechanical performance demonstrated that the void ratio and water permeability increased with increasing the mixing ratio of bottom ash. The strength of the concrete tended to decrease as the mixing ratio of the bottom ash aggregate increased. However, the strength could be improved by the addition of polymers, e.g., when coal ash was used in porous vegetation concrete for secondary products and paving materials [3-10]. Another study evaluated the engineering characteristics and vegetation features of a porous concrete block made with rice straw ash, which is an agricultural byproduct [13]. The compressive strength and flexural rigidity were evaluated as a function of its void ratio, time to neutralization and cure [13]. Diverse plants such as lawn, chamssari (Lespedeza cyrtobotrya Miq.) and bisuri (Chinese bush-clover) were planted in the developed porous block to establish vegetation features [13]. The void ratio decreased and the strength increased with increasing the mixing ratio of rice straw ash. The strength of the neutralized block was greatest after six days of curing [13]. Concerning the vegetation on the porous vegetation concrete block, the growth rate of lawn was greater than chamssari and bisuri [13]. While chamssari and bisuri had lower early growth rates, their long-term growth was excellent; they showed a similar growth length as that found in ordinary soil [13]. Crushed stone has also been widely used as aggregate in concrete. However, other aggregates are now being sought because of environmental and conservation issues concerning crushed stone. Blast furnace slag aggregate is among the substitutes being considered $[16,17]$. Similar to blast furnace slag, blast furnace slag aggregate is a byproduct of the steel industry. Therefore, substitution of blast furnace slag aggregate for crushed stone would be very effective for resource recycling and for environmental protection $[16,17]$. Blast furnace slag cement is an industrial byproduct. In this study, blast furnace slag cement and blast furnace slag aggregate were used instead of natural aggregate to produce an eco-friendly porous vegetation concrete block. Hydraulic stability testing was conducted to evaluate its physical and vegetational performance in the field.

\section{Materials and Methods}

\subsection{Materials}

The blast furnace slag cement used in this study had a $60 \%$ substitution rate of blast furnace slag; its physical and chemical properties are listed in Table 1 . The blast furnace slag aggregate consisted of grains about $25-28 \mathrm{~mm}$ in size. Its density was $2.36 \mathrm{~g} / \mathrm{cm}^{3}$, the absorption rate was $5 \%$ and the absolute volumetric mass was $1.56 \mathrm{~kg} / \mathrm{L}$. The crushed aggregate was quite coarse, with a maximum grain size of $25 \mathrm{~mm}$ and density of $2.65 \mathrm{~g} / \mathrm{cm}^{3}$. The latex used in this study was Styrene Butadiene; SB latex, the characteristics of which are shown in Table 2. 
Table 1. Properties of blast furnace slag cement.

\begin{tabular}{cccccccc}
\hline \multirow{2}{*}{$\begin{array}{c}\text { Fineness } \\
\left(\mathbf{c m}^{2} / \mathbf{g}\right)\end{array}$} & $\begin{array}{c}\text { Specific } \\
\text { Gravity }\end{array}$ & $\begin{array}{c}\text { Stability } \\
\mathbf{( \% )}\end{array}$ & \multicolumn{2}{c}{ Setting Time } & \multicolumn{3}{c}{ Compressive Strength (MPa) } \\
\cline { 4 - 8 } & & & Initial (min) & Final (min) & 3 Days & 7 Days & 28 Days \\
\hline 4330 & 3.02 & 1 & 265 & $6: 15$ & 20.6 & 29.8 & 54.5 \\
\hline
\end{tabular}

Table 2. Properties of SB latex.

\begin{tabular}{cccccccc}
\hline $\begin{array}{c}\text { Solids } \\
\text { Content } \\
(\%)\end{array}$ & $\begin{array}{c}\text { Styrene } \\
\text { Content } \\
(\%)\end{array}$ & $\begin{array}{c}\text { Butadiene } \\
\text { Content } \\
(\%)\end{array}$ & pH & $\begin{array}{c}\text { Specific } \\
\text { Gravity }\end{array}$ & $\begin{array}{c}\text { Surface } \\
\text { Tension } \\
(\text { dyne/cm) }\end{array}$ & $\begin{array}{c}\text { Particle } \\
\text { Size (A) }\end{array}$ & $\begin{array}{c}\text { Viscosity } \\
\text { (cps) }\end{array}$ \\
\hline 46.5 & $34 \pm 1.5$ & $66 \pm 1.5$ & 11.0 & 1.02 & 30.57 & 1700 & 42 \\
\hline
\end{tabular}

\subsection{Mix Proportions}

In this study, the basic mixing ratio was established after a survey of the literature and from an analysis of previous studies of vegetation concrete block. The substitution ratio of blast furnace slag aggregate was set at $40 \%$. The mixing ratio depended on the added amount of latex, as shown in Table 3. The purpose of this study was to develop a porous vegetation concrete having sufficient structural stability that would easily support plant growth. The specifications for porous vegetation concrete are given in the environmental declaration EL245 for Water-permeable Concrete Pavements issued by the Korean Ministry of the Environment [18]. The specifications are as follows: $12 \mathrm{MPa}$ or higher compressive strength, $25 \%$ or higher void ratio and $80 \%$ or higher residual compressive strength after repeated freezing-thawing. This study also aimed to meet the specifications proposed by the environmental declaration.

Table 3. Mixture design of porous vegetation concrete.

\begin{tabular}{|c|c|c|c|c|c|}
\hline \multirow{3}{*}{ No. of Mix } & \multicolumn{5}{|c|}{ Unit Weight $\left(\mathrm{kg} / \mathrm{m}^{3}\right)$} \\
\hline & \multirow{2}{*}{ Water } & \multirow{2}{*}{ BFS* Cement } & \multicolumn{2}{|c|}{ Aggregate } & \multirow{2}{*}{ SB Latex } \\
\hline & & & $25 \mathrm{~mm}$ & BFS & \\
\hline Plain & 79 & 306 & 1412 & 0 & 0 \\
\hline BFS & 79 & 306 & 847 & 565 & 0 \\
\hline BFS-latex & 75 & 306 & 847 & 565 & 6.2 \\
\hline
\end{tabular}

\subsection{Laboratory Test Methods}

Porous vegetation concrete is a material with pores in which plants can live. Thus, the void ratio is a very important factor. With a low void ratio, the strength may increase but the growth of plants is more difficult. A high void ratio may decrease the strength. Therefore, it is critical to achieve the appropriate void ratio. This study examined how the void ratio of porous vegetation concrete was influenced by the addition of blast furnace slag aggregate, natural jute fiber and latex. The void ratio was measured using a conical specimen of $100 \mathrm{~mm}$ diameter and $200 \mathrm{~mm}$ height according to the volumetric method "Void Ratio Test Methods (Proposed) for Porous Concrete" issued by the Eco-Concrete Research Commission of Japan Concrete Industrial Association. It was calculated according to Equation (1) on the 28th day.

$$
\mathrm{P}_{\mathrm{a}}=1-\frac{\mathrm{W}_{2}-\mathrm{W}_{1}}{\mathrm{~V}} \times 100
$$

where $W_{1}$ and $W_{2}$ are the underwater and air-dried weights of the specimen, respectively, and $V$ is the volume of the specimen. 
For the void ratio measurement, a conical specimen was initially cured for $24 \mathrm{~h}$ after production at $23 \pm 2{ }^{\circ} \mathrm{C}$ and about $58 \%$ relative humidity. It was then removed from the mold and cured by immersion in water for three days in the curing room at $23 \pm 2{ }^{\circ} \mathrm{C}$ before measurement. In this study, a water-cured specimen was dried for $24 \mathrm{~h}$ in an oven at $105 \pm 5{ }^{\circ} \mathrm{C}$ to ensure that it was absolutely dry, and then the void ratio was measured. The compressive strength was measured according to the standard ASTM C39/C39M-15a [19]. A specimen of $100 \mathrm{~mm}$ diameter and $200 \mathrm{~mm}$ height was produced and initially cured for $24 \mathrm{~h}$ at $23 \pm 2{ }^{\circ} \mathrm{C}$ and about $58 \%$ relative humidity. It was removed from the mold after $24 \mathrm{~h}$ and then cured in water for 28 days in the curing room at $23 \pm 2{ }^{\circ} \mathrm{C}$. Continuous soaking of porous vegetation concrete applied to revetment may be problematic. Also, repetitive soaking and drying cycles and freezing may cause expansion and crack formation. Hence, it is necessary to evaluate its durability. In this study, the freeze-thaw resistance of porous vegetation concrete was analyzed [20]. The method used 100 freeze-thaw cycles, according to the requirements of the environmental declarations (EL245, Water-permeable Concrete Pavements; EL745, Blocks, Tiles and Board Materials) and the group declaration (SPS-KCIC0001-0703) [21].

\section{Results and Discussion}

Figure 1a shows the void ratio test results as a function of the blast furnace slag aggregate, natural linen fibers and latex contents. Blast furnace slag aggregate increased the void ratio of the porous vegetation concrete more than crushed aggregate. The void ratio probably increased because of the higher void ratio of the blast furnace slag aggregate. The target or designed void ratio of $25 \%$ or higher was achieved by mixing blast furnace slag aggregate and latex. The compressive strength results are shown in Figure 1b. The compressive strength of the porous vegetation concrete tended to be lower when blast furnace slag aggregate was used. It is likely that the high void ratio of the blast furnace slag aggregate greatly delayed the strength development, similar to the effect of blast furnace slag powder. The addition of latex helped to increase the compressive strength. The latex increased the early fluidity and promoted coating of the binder around the aggregates and the cohesion of aggregate grains. The target compressive strength of $12 \mathrm{MPa}$ or higher was satisfied by all of the mixtures. The freeze-thaw resistance results are shown in Figure 1c. After 28 days of curing, the freezing-thawing was repeated 100 times and then the compressive strength was measured. The compressive strength tended to decrease regardless of the addition of blast furnace slag aggregate and latex. The mixture with blast furnace slag aggregate showed less reduction in compressive strength after the freezing-thawing than that with crushed aggregate. It is likely that the blast furnace slag powder and the blast furnace slag aggregate behaved as pseudo-pozzolanic materials and generated a continuous hydration reaction, which increased the strength. The presence of latex reduced the drop in compressive strength after repetitive freezing-thawing. It increased the early fluidity of the porous concrete by promoting coating of the binder on the boundary surface between the aggregates, thereby strengthening the boundary and increasing the cohesion of the aggregate grains. After 100 freeze-thaw cycles, the target of $80 \%$ or higher residual compressive strength was achieved by all of the mixtures containing blast furnace slag and latex; the plain mixture did not meet this criterion. The combination of blast furnace slag powder, blast furnace slag aggregate and latex provided adequate freeze-thaw resistance.

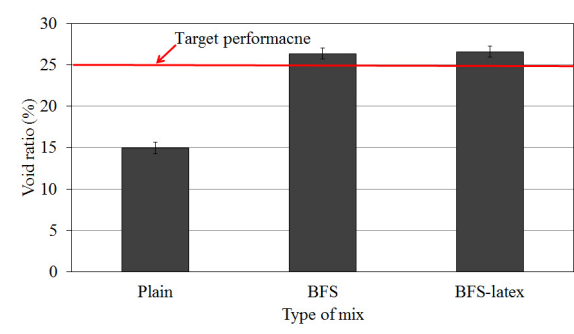

(a)

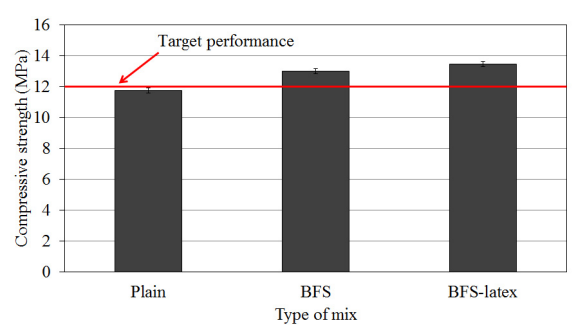

(b)

Figure 1. Cont. 


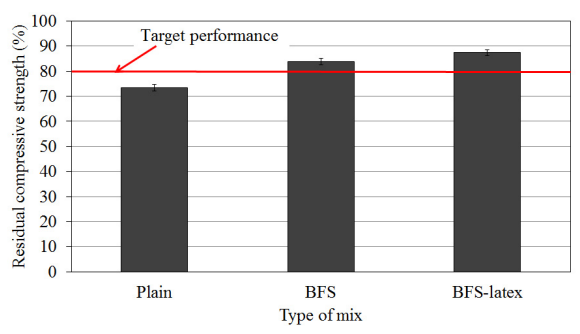

(c)

Figure 1. Laboratory test results. compressive strength.
(a) Void ratio;
(b) Compressive strength;
(c) Residual

\section{Determination of the Optimal Mix Proportion}

The porous vegetation concrete with latex had higher compressive strength, void ratio and freeze-thaw resistance. The target values were satisfied by almost all of the mixtures containing latex. Mixtures with latex were considered as essential for porous vegetation concrete block (Table 3: BFS-latex). The best composition had a compressive strength of $14.32 \mathrm{MPa}$, a void ratio of $27.41 \%$ and a residual compressive strength of $87.38 \%$ after repeated freeze-thaw cycles.

\section{Application in the Field}

\subsection{Design and Manufacture of the Porous Vegetation Concrete}

The porous vegetation concrete block is meant for relatively slow rivers. It can prevent uneven sinking of the riverbed if plants can attach to it and their roots can pass through the block to reach the ground, thereby joining the block with the ground. The specification of the porous vegetation concrete block in this study had rounded corners. It had dimensions of $100 \times 100 \mathrm{~mm}$ with a thickness of $20 \mathrm{~mm}$ (about one-fifth the size of an actual porous vegetation blocks), weight of $\geqslant 30$ (kg/each) and tractive force of $16 \mathrm{~kg} / \mathrm{m}^{2}$. When porous vegetation blocks are used for slanted slopes, they are mainly placed on the riverbanks. The soil covering the block can be kept when the slope of a bank is 1:2 or higher. However, when the slope is less than 1:2, the soil can be easily lost. In that case, it is necessary to make a sill on the far side of the slope to prevent flow-down of the soil. Figure 2 shows the design of the porous vegetation block. Because the total thickness of the product was $100 \mathrm{~mm}$ and the thickness of the covering soil was 50-100 mm, the sufficient supply of water and favorable climatic conditions (May-June) enabled plant roots to migrate through the pores within three months. However, it was difficult to provide sufficient water until the plants had fully settled down. For this reason, some of the blocks were grooved in a U-shape to make them slightly thinner; this helped the plants to more easily settle and flourish until they could provide shade, which then facilitated the settlement of other plants. The thickness of the U-shaped part was set at $60 \mathrm{~mm}$. Porous vegetation concrete blocks were manufactured as follows: The concrete paste mixed from the raw materials was poured into a metal mold and then packed using a vibrational compressor. Too long a vibrational compaction time can lead to the fluidizing of cement and filling of pores. Therefore, the vibrational compaction time was controlled to about 10-12 s. Currently, in Korea, a process for steam-curing the porous vegetation concrete in production methods has been conducted. The reason for applying the steam-curing is to increase the production volume due to the rapid curing. The cost of the steam-curing process is increased. However, steam-curing is possible for reducing the space required for the air-curing, thus increasing the economic efficiency of the product according to the decrease in storage space. For the steam-curing process, for $2 \mathrm{~h}$ the concrete was exposed to air at $25^{\circ} \mathrm{C}$, and after, the temperature was raised to $65^{\circ} \mathrm{C}$ for $1 \mathrm{~h}$. It was maintained at $65^{\circ} \mathrm{C}$ for $6 \mathrm{~h}$. Then the temperature was reduced to $25^{\circ} \mathrm{C}$ for $1 \mathrm{~h}$. Air-curing was carried out after the steam-curing. Figure 3 shows the steam-curing process of porous vegetation concrete blocks. 


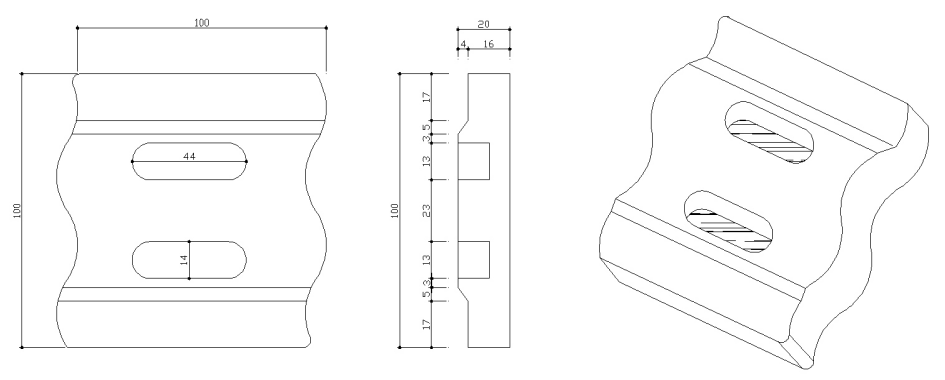

(a)

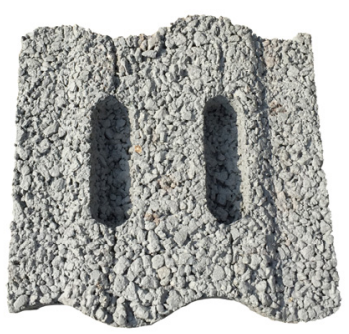

(b)

Figure 2. Drawings and photo of small porous vegetation concrete block. (a) Drawing; (b) Product.

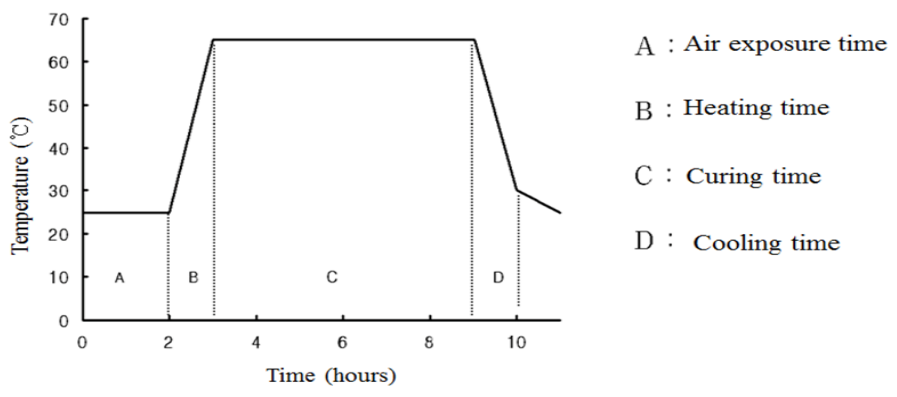

Figure 3. Steam-curing process for porous vegetation concrete blocks.

\subsection{Target Performance Analysis}

The mechanical properties of the porous vegetation concrete block were measured. The produced block was tested for compressive strength and, after freezing-thawing, for residual compressive strength and void ratio. The compressive strength was $13.6 \mathrm{MPa}$; after freezing-thawing, the residual compressive strength was $85.3 \%$ and the void ratio was $27.2 \%$ (Table 4 ). These results satisfied the target value, i.e., a compressive strength of $12 \mathrm{MPa}$ or higher and, after freezing-thawing, a residual compressive strength of $80 \%$ or higher and a void ratio of $25 \%$ or higher. The heavy metal leaching test was also carried out; the result is shown in Table 5. Only copper was leached; the measured value of $0.044 \mathrm{mg} / \mathrm{L}$ satisfied the requirement of $3 \mathrm{mg} / \mathrm{L}$ or lower. The oily component was less than $0.1 \%$, which also satisfied the necessary $5 \%$ or lower. 
Table 4. Mechanical property test results on porous vegetation concrete block.

\begin{tabular}{|c|c|c|c|c|c|c|c|c|c|}
\hline \multirow{2}{*}{\multicolumn{2}{|c|}{ Types of Test }} & \multirow{2}{*}{ Unit } & \multicolumn{6}{|c|}{ Test Result } & \multirow{2}{*}{ Target } \\
\hline & & & 1 & 2 & 3 & 4 & 5 & Mean & \\
\hline \multicolumn{2}{|c|}{ Compressive strength } & $\mathrm{MPa}$ & 14.5 & 13.3 & 12.8 & 14.3 & 13.2 & 13.6 & $\geqslant 12$ \\
\hline \multirow{3}{*}{$\begin{array}{c}\text { Repeated } \\
\text { freezing-thawing } \\
(100 \text { cycles })\end{array}$} & Compressive strength & $\mathrm{MPa}$ & 12.4 & 11.3 & 10.9 & 12.2 & 11.2 & 11.6 & - \\
\hline & Compressive strength ratio & $\%$ & 14.5 & 15.0 & 14.8 & 14.7 & 15.2 & 14.7 & $\leqslant 20$ \\
\hline & Void ratio & $\%$ & 26.5 & 27.3 & 26.6 & 28.4 & 27.2 & 27.2 & $\geqslant 25$ \\
\hline
\end{tabular}

Table 5. Heavy metal leaching test results on porous vegetation concrete block.

\begin{tabular}{ccccc}
\hline Test Item & Unit & Value & \multicolumn{2}{c}{ Standard } \\
\hline $\mathrm{Pb}$ & & $\mathrm{N} / \mathrm{A}$ & $\leqslant$ & 3 \\
$\mathrm{Cr}$ & $\mathrm{N} / \mathrm{A}$ & $\leqslant$ & 1.5 \\
$\mathrm{Cu}$ & 0.044 & $\leqslant$ & 3 \\
$\mathrm{Cd}$ & $\mathrm{N} / \mathrm{A}$ & $\leqslant$ & 0.3 \\
$\mathrm{As}$ & & $\mathrm{N} / \mathrm{A}$ & $\leqslant$ & 1.5 \\
$\mathrm{Hg}$ & $\mathrm{Ng} / \mathrm{L}$ & $\mathrm{N} / \mathrm{A}$ & $\leqslant$ & 0.005 \\
$\mathrm{CN}^{-}$ & & $\mathrm{N} / \mathrm{A}$ & $\leqslant$ & 1 \\
Organophosphorus & & $\mathrm{N} / \mathrm{A}$ & $\leqslant$ & 1 \\
TCE & $\mathrm{N} / \mathrm{A}$ & $\leqslant$ & 0.3 \\
$\mathrm{PCE}$ & & & $\leqslant$ & 0.1 \\
\hline Oil & & $\leqslant 0.1$ & & 5 \\
composition & $\%$ & &
\end{tabular}

\subsection{Hydraulic Stability Evaluation and Analysis}

The hydraulic stability of the porous vegetation concrete block when used as a river revetment is very important. The results of testing using the hydraulic model must be scalable to ensure good agreement with the full-scale block. The power of the flow is very important in the actual situation. Power should govern the flow even in the reduced model. If the scale of the model is too small, then the water depth becomes so shallow that the influence of the adhesive power cannot be ignored. Therefore, to exclude such undesirable effects of model reduction, the specific dimensions must be followed to maintain the correlation with the same dominant power. In this study, the flow rate, roughness coefficient and tractive force of the hydraulic scale model were calculated using Froude's similitude law. The hydraulic model was evaluated in an open water channel where the maximum flow was $0.375 \mathrm{~m}^{3} / \mathrm{s}$, the cistern capacity was $60 \mathrm{~m}^{3}$, the channel length was $20 \mathrm{~m}$, the width was $2 \mathrm{~m}$ and the height was $1 \mathrm{~m}$. The produced blocks were installed on both sides of the open channel with a slope of 1:3. The hydraulic model was tested under three conditions in consideration of the presence of vegetation, i.e., $0.100,0.200$ and $0.250 \mathrm{~m}^{3} / \mathrm{s}$. The effect of the slope of the water channel on the hydraulic model was also evaluated under three conditions, i.e., $0.000,0.001$ and $0.002 \mathrm{~m} / \mathrm{m}$. The water level and the flow rate were measured at the center of each block in the direction of flow and then from the center to the rim at intervals of $20 \mathrm{~cm}$. The Froude number, average flow rate, roughness coefficient and tractive force were calculated using the sectional average values. The test parameters for the scaled hydraulic model are detailed in Table 6 . Figure 4 shows how the water level and flow rate were measured. The block was installed in a location free of flowing sands and where the water level and flow rate could be readily measured. The test block model had the dimensions of $0.1 \mathrm{~m} \times$ $0.1 \mathrm{~m} \times 0.02 \mathrm{~m}$ (thickness), which was one-fifth the size of an actual vegetation block. The blocks were installed on both sides of the open water channel over an area of $0.45 \mathrm{~m} \times 3.0 \mathrm{~m}=1.35 \mathrm{~m}^{2}$. The height of the installed block was $0.02 \mathrm{~m}$. The weight of each block was $0.3 \mathrm{~kg}$ and the total number of blocks installed on both sides was 560. Slope plates were installed at the starting and ending points of the revetment where the blocks were laid. The slope plates were attached with silicone adhesive to the 
channel bottom. A mat-type of natural lawn grass was used for the vegetation (Figure 5); its sectional structure is shown in Figure 6. Figure 7 shows a view of the hydraulic model.

Table 6. Plan of the hydraulic model experiment (accumulation).

\begin{tabular}{ccc}
\hline Types & Discharge $\left(\mathrm{m}^{3} / \mathrm{s}\right)$ & Channel Slope $(\mathrm{m} / \mathrm{m})$ \\
\hline $\begin{array}{c}\text { With plants } \\
\text { Without plants }\end{array}$ & $0.100,0.200,0.250$ & $0.000,0.001,0.002$ \\
\hline
\end{tabular}

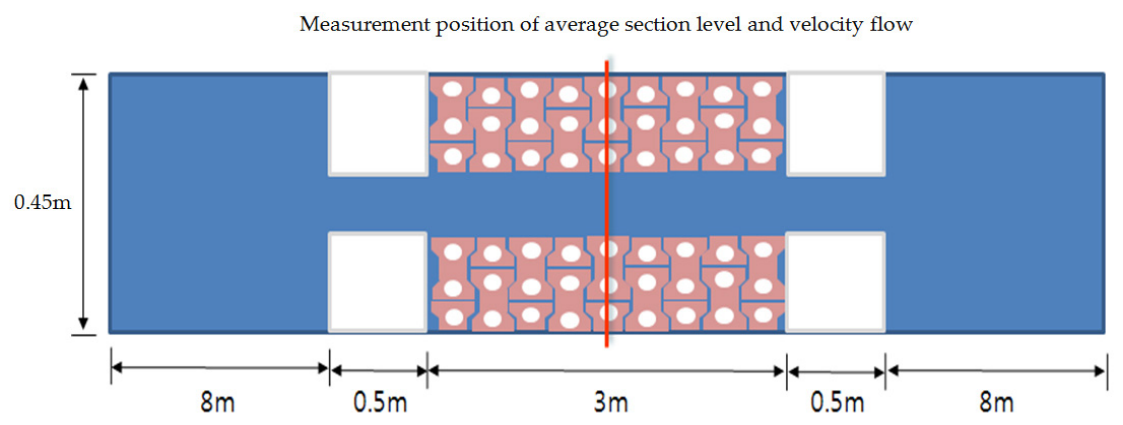

Figure 4. Measurement position of average section level and velocity flow.
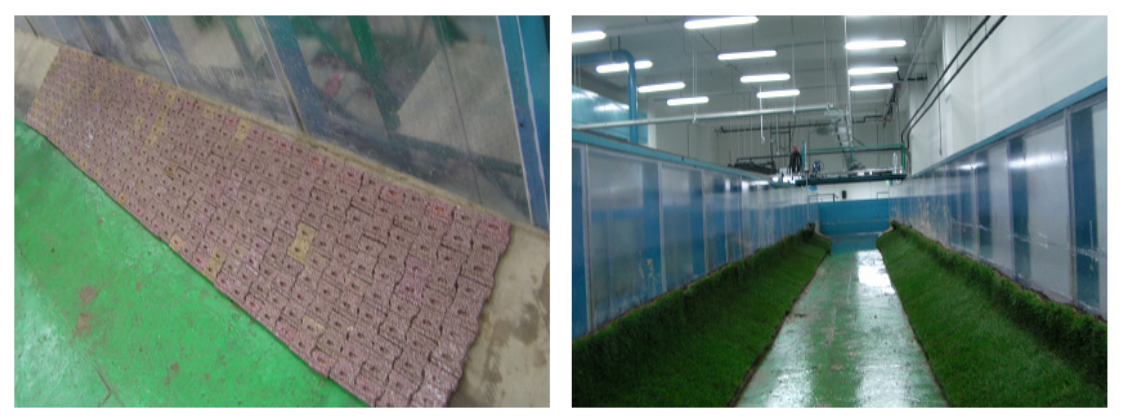

Figure 5. Set-up of hydraulic model experiment.

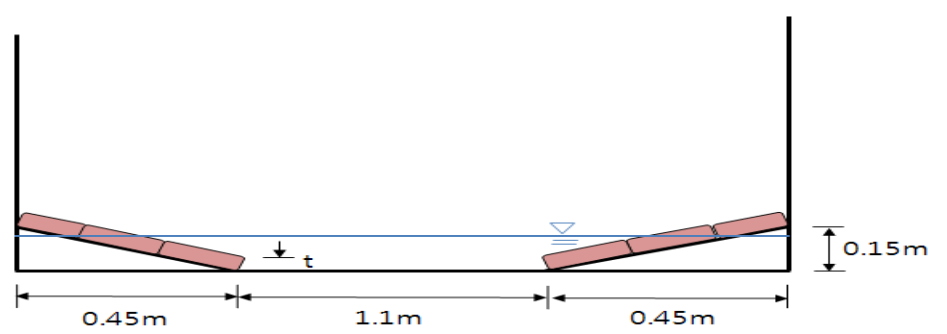

Figure 6. Cross-section of hydraulic model experiment.

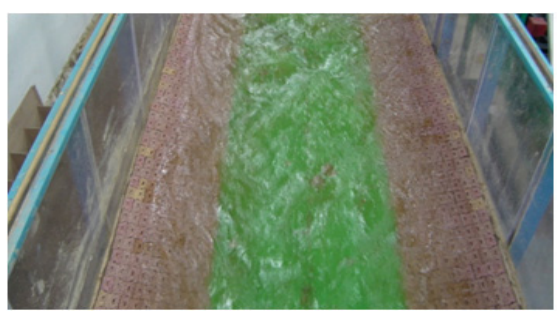

(a)

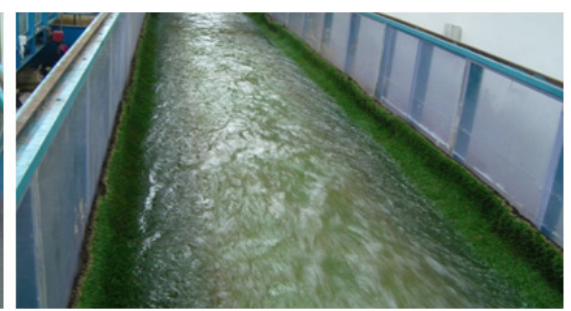

(b)

Figure 7. Photo of hydraulic model experiment. (a) Without plant; (b) With plant. 


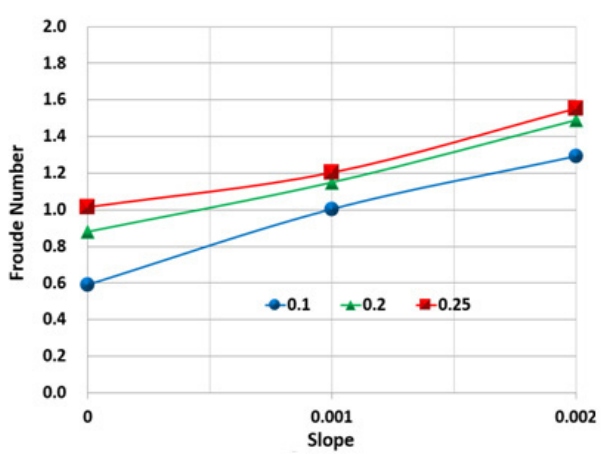

(a)

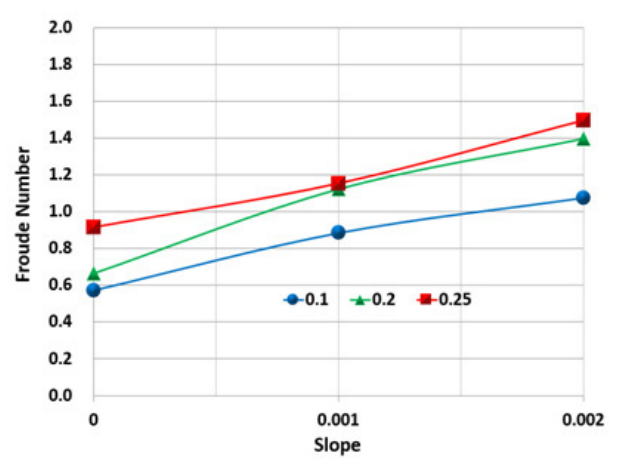

(b)

Figure 8. Results of Froude number. (a) Without plant; (b) With plant.

The Froude number, average flow rate, roughness coefficient and tractive force were calculated for the hydraulic scale model for the cases with and without vegetation. The limiting values of the flow rate and tractive force of the block could not be determined. Instead, the similitude law model was used to compare and verify the converted results with the original ones. Figure 8 gives the Froude numbers calculated for each flow rate and channel slope. Without vegetation, it ranged from 0.59-1.55, while with vegetation it was $0.57-1.45$. A Froude number of $F_{f}<1$ corresponds to subcritical flow, $F_{f}=1$ to critical flow and $F_{f}>1$ to supercritical flow. The Froude number increased, changing from subcritical flow to supercritical flow, with increasing flow rate and slope. The average flow rate was measured for each flow rate and channel slope at the middle section where the revetment was installed. The results are shown in Figure 9. Without vegetation, the flow rate was $0.649-1.718 \mathrm{~m} / \mathrm{s}$; with vegetation, it was $0.628-1.682 \mathrm{~m} / \mathrm{s}$. The average flow rate increased with increasing flow rate and channel slope. The roughness coefficient was calculated using Manning's average flow rate theorem. It varied with the flow rate and the channel slope from 0.019-0.020 without vegetation and from 0.019-0.021 with vegetation (Figure 10). The tractive force was calculated for each flow rate and channel slope, with and without vegetation being present. The results are shown in Figure 11. The tractive force was $0.76-2.44 \mathrm{~kg} / \mathrm{m}^{2}$ without vegetation and $0.72-2.38 \mathrm{~kg} / \mathrm{m}^{2}$ with vegetation. The tractive force increased with increasing flow rate and channel slope. It was necessary to convert the hydraulic scale model test results to validate the model. The hydraulic values-such as average flow rate, roughness coefficient and tractive force-obtained with the reduced model were converted into the original block values by using Froude's similitude law. These results were compared with those of previous studies. The original sectional average flow rate for each flow rate and channel slope with and without vegetation was calculated using Froude's similitude law; the results are shown in Figure 12. Without vegetation, it ranged from $1.45-3.84 \mathrm{~m} / \mathrm{s}$; with vegetation, it was $1.40-3.76 \mathrm{~m} / \mathrm{s}$. The sectional average flow rate increased with increasing flow rate and channel slope. The flow rate decreased slightly in the presence of vegetation. Therefore, porous vegetation concrete will be able to reduce peak flooding during heavy rainfall better than ordinary concrete revetment blocks without vegetation, thereby mitigating flood risks. Furthermore, as the plant grows to cover the ground, it can provide living space for animals. Furthermore, by promoting the accumulation of sand, it contributes to regenerating nature. The results of the roughness coefficient measurements are shown in Figure 13. Without vegetation, they ranged from $0.025-0.027$, while they were between $0.025-0.028$ with vegetation. The converted results of the tractive force are shown in Figure 14. Without vegetation, it ranged from $3.79-12.22 \mathrm{~kg} / \mathrm{m}^{2}$; with vegetation, it was $3.58-11.91 \mathrm{~kg} / \mathrm{m}^{2}$. The tractive force increased with increasing flow rate and channel slope. The tractive force for the original block and the allowable one for different types of revetment were compared to evaluate the hydraulic stability of the porous vegetation concrete block. The tractive force for the original block, calculated from testing of the reduced hydraulic model, is shown in Table 7. Table 8 presents the allowable tractive force for different revetments, extracted from Newest Riparian Engineering (2005), published by the Korean Society of Civil Engineering [22]. Comparison of 
the data given in Table 7 with those in Table 8 revealed that the tractive force of porous vegetation concrete lay between $7.0 \mathrm{~kg} / \mathrm{m}^{2}$ for fascine revetment (vegetation revetment) and $16.0 \mathrm{~kg} / \mathrm{m}^{2}$ for stone pitching (hard revetment). Thus, porous vegetation concrete had sufficient hydraulic stability for the field application.

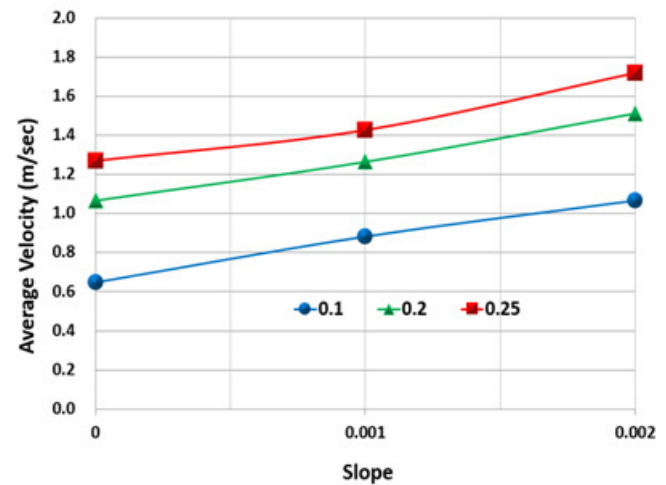

(a)

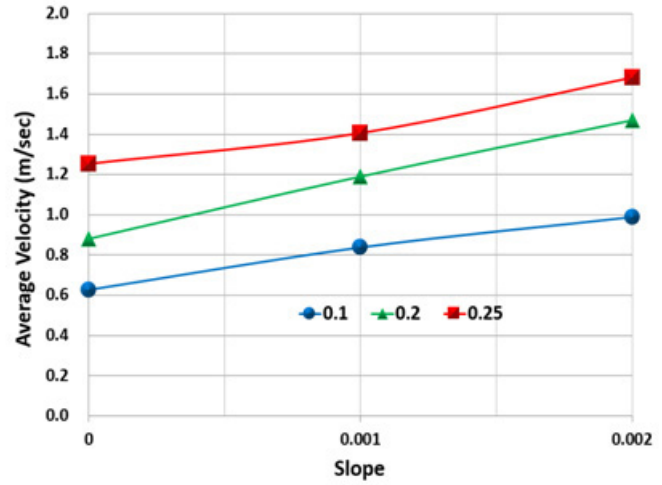

(b)

Figure 9. Results of sectional average velocity flow. (a) Without plant; (b) With plant.

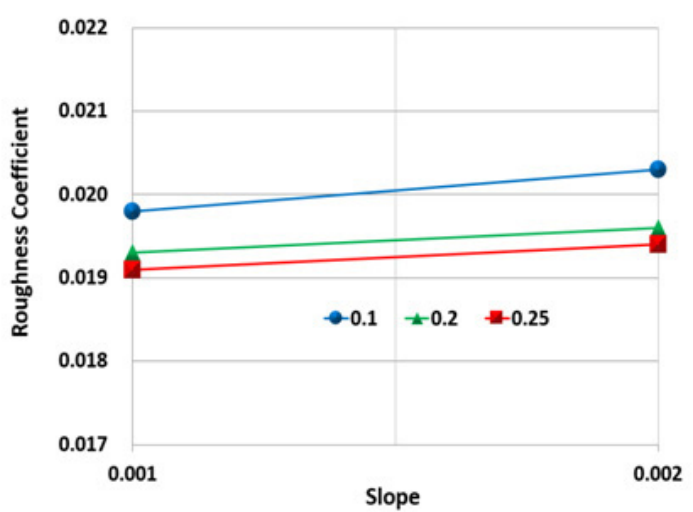

(a)

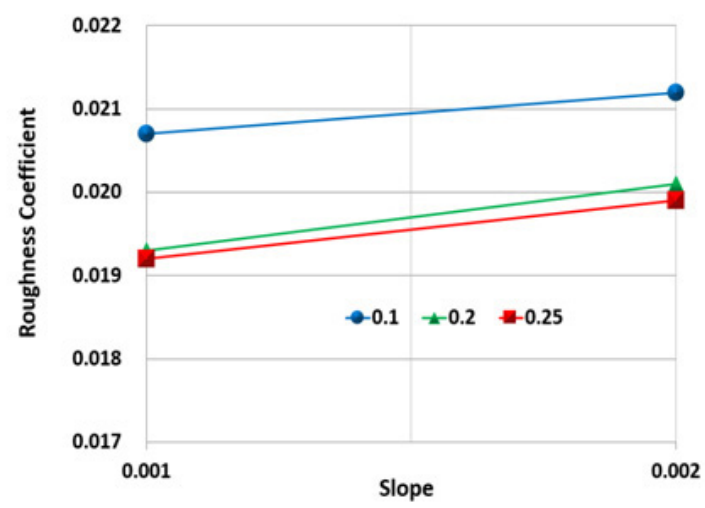

(b)

Figure 10. Results of roughness coefficient. (a) Without plant; (b) With plant.

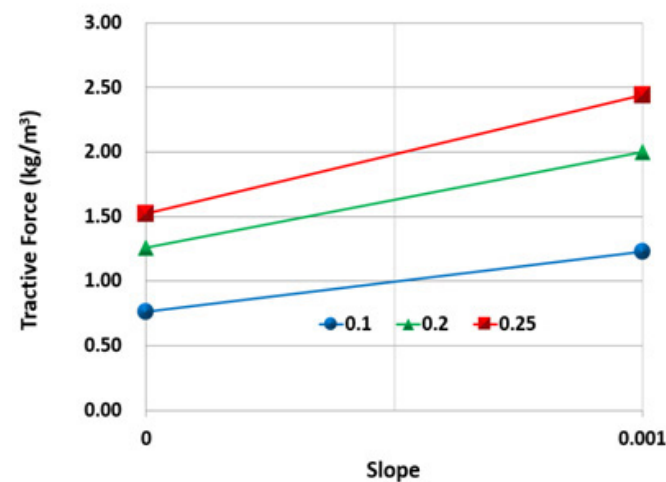

(a)

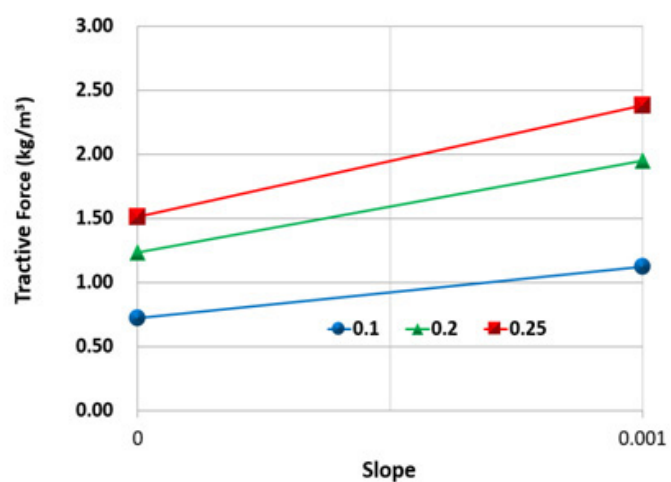

(b)

Figure 11. Results of tractive force. (a) Without plant; (b) With plant. 


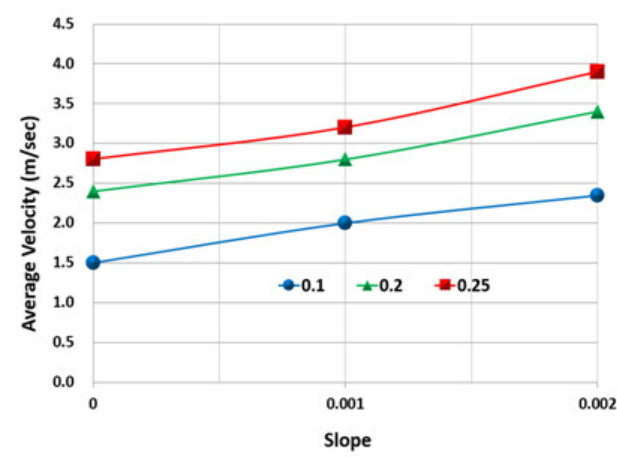

(a)

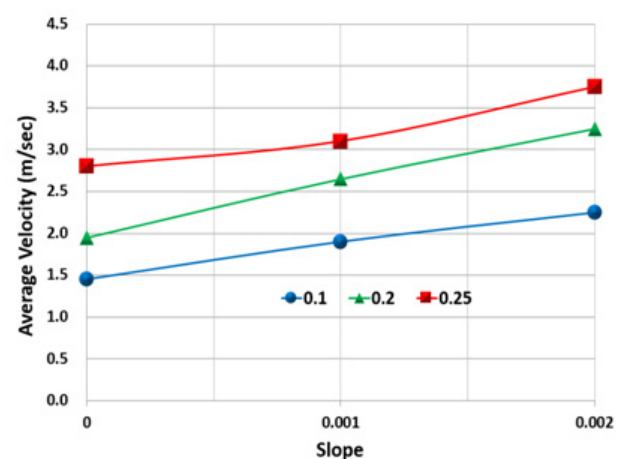

(b)

Figure 12. Results of sectional average velocity flow (scale of 5/1). (a) Without plant; (b) With plant.

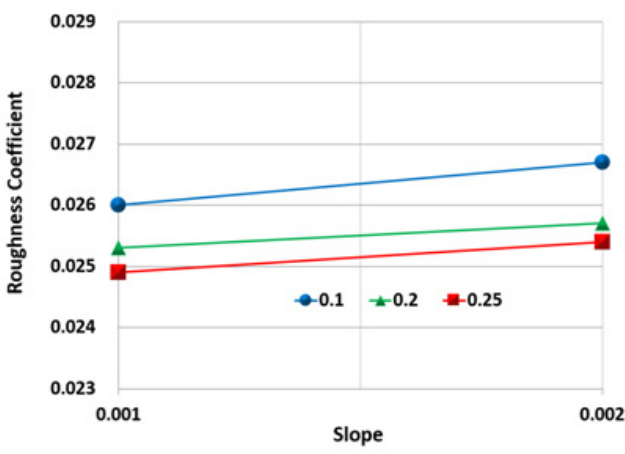

(a)

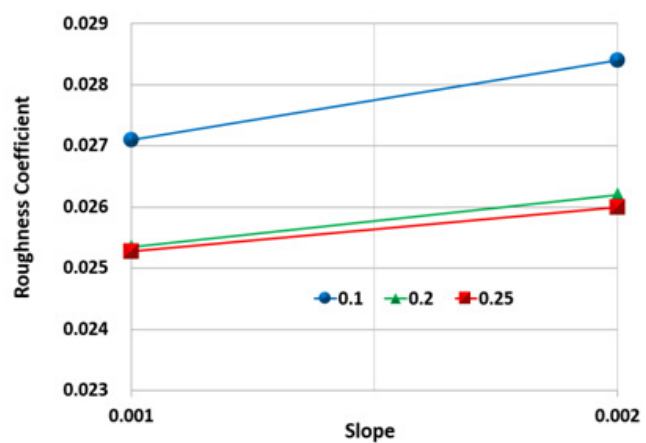

(b)

Figure 13. Results of roughness coefficient (scale of 5/1). (a) Without plant; (b) With plant.

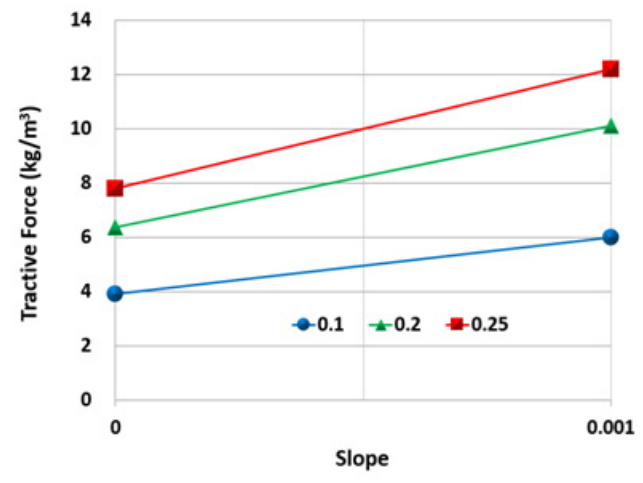

(a)

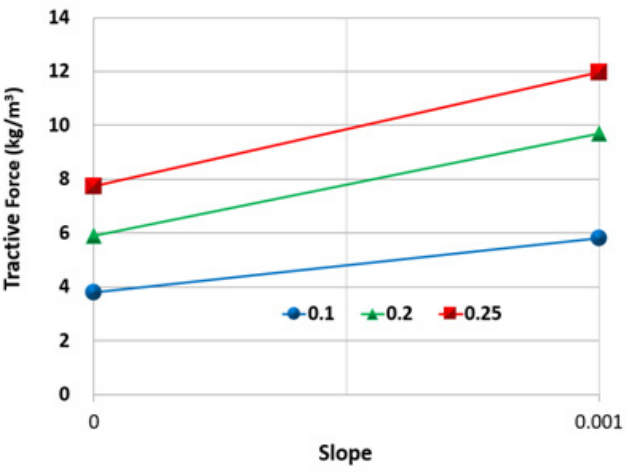

(b)

Figure 14. Results of tractive force (scale of 5/1). (a) Without plant; (b) With plant.

Table 7. Evaluation of hydraulic stability.

\begin{tabular}{|c|c|c|c|c|}
\hline \multirow{4}{*}{ Discharge $\left(\mathrm{m}^{3} / \mathrm{s}\right)$} & \multicolumn{4}{|c|}{ Channel Slope $(\mathrm{m} / \mathrm{m})$} \\
\hline & \multicolumn{2}{|c|}{0.001} & \multicolumn{2}{|c|}{0.002} \\
\hline & Without Plants & With Plants & Without Plants & With Plants \\
\hline & Tractive Force $\left(\mathrm{kg} / \mathrm{m}^{2}\right)$ & Tractive Force $\left(\mathrm{kg} / \mathrm{m}^{2}\right)$ & Tractive Force $\left(\mathrm{kg} / \mathrm{m}^{2}\right)$ & Tractive Force $\left(\mathrm{kg} / \mathrm{m}^{2}\right)$ \\
\hline 0.100 & 3.79 & 3.58 & 6.04 & 5.81 \\
\hline 0.200 & 6.47 & 5.86 & 10.11 & 9.74 \\
\hline 0.250 & 7.73 & 7.58 & 12.22 & 11.91 \\
\hline
\end{tabular}


Table 8. Critical tractive force of revetment materials (Schoklitsch).

\begin{tabular}{cccc}
\hline $\begin{array}{c}\text { Type of Revetment } \\
\text { Material }\end{array}$ & $\begin{array}{c}\text { Critical Tractive Force } \\
\left(\mathbf{k g} / \mathbf{m}^{\mathbf{2}}\right)\end{array}$ & $\begin{array}{c}\text { Type of Revetment } \\
\text { Material }\end{array}$ & $\begin{array}{c}\text { Critical Tractive Force } \\
\left(\mathbf{k g} / \mathbf{m}^{\mathbf{2}}\right)\end{array}$ \\
\hline Planted grass & 2.0 & $\begin{array}{c}\text { Stone pitching } \\
\left(\text { Slope } 1: 1, \mathrm{~T}^{*}=0.3 \mathrm{~m}\right)\end{array}$ & 16.0 \\
\hline Coarse sand from bag & 1.0 & Large riprap & 24.0 \\
\hline Gravel from bag & 1.5 & Stone masonry & 60.0 \\
\hline Brushwood & 6.0 & Concrete wall & 60.0 \\
\hline Fascine revetment & 7.0 & Cribwork & 150 \\
\hline \multicolumn{2}{c}{$\mathrm{T}^{*}$, thickness. }
\end{tabular}

\subsection{Field Construction and Analysis}

Figure 15 shows the process of the application of porous vegetation concrete block products. The first step is manufacturing the blocks. The second is installing the blocks on the slope of the riverbank. The construction should always be made in consideration of the plant growth conditions. Planting is the final process; this should be made after selecting those plants appropriate for the field by considering their sowing time, soil condition, germination percentage and growth level. For the planting step, all of the materials were mixed with unpolluted water according to the specified mixing ratio. This ensured a viscosity that was appropriate for spraying from a specialized planting vehicle using a compressor. When planted on the blocks, the planting materials were sprayed from top to bottom, and from left to right and vice versa, repeatedly, to cover the attached area evenly without flowing down. The coating material contained the organic fermentation soil that provided insulation, moisturizing and single-graining effects and contained diverse greening agents. The anti-erosion soil stabilizer encourages the combination of many organic materials to maintain a uniform mixing state, reduces mobility, prevents erosion and promotes early sprouting. The coated surface of the slope was protected with mats and then irrigated after the plant seeds were sown. The mat helps the early sprouting of seeds with moisturizing and sun-screening. After installation on the slope, the mat was fixed with pins on the top and bottom sides. Then, the mats were secured with vinyl or jute ropes at regular intervals.

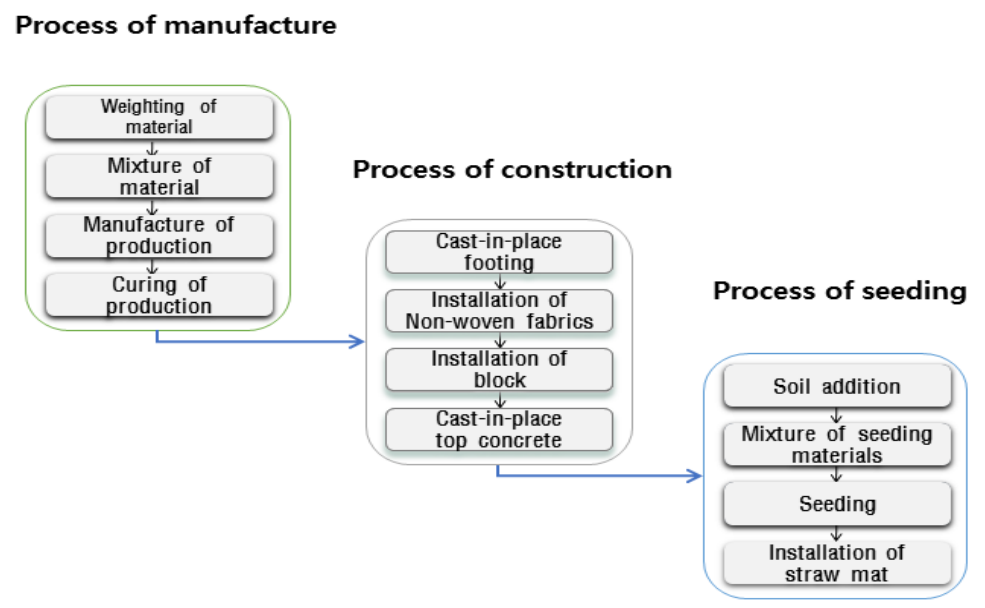

Figure 15. Process of construction method.

Figure 16 shows how the porous vegetation concrete blocks were installed. A detailed description of the installation process is as follows. The riverbed of a small river was first cleaned and the ground was dug. The basic blocks were then put in place, the ground was back-filled and the slope was 
cleaned. Then, the unwoven cloth was spread and the porous vegetation concrete blocks were installed. Soil was then applied (10 cm thick) on top. Seeds were then planted in the soil. All of the planting materials were mixed in unpolluted water according to the specified mixing ratio and sprayed from the specialized planting vehicle. The mixing ratio of the various seeds applied to the field test site is shown in Table 9. In total, 13 kinds of seeds (11 wild flowers, two lawn grasses) were used. The seeds were sprayed from top to bottom, and from left to right and vice versa, repeatedly, to cover the attached slope surface evenly without flowing down. Finally, the coated surface of the slope was covered with mats for irrigation and protection from the sun and the mats were fixed with pins on the top and bottom sides. The mats were attached with vinyl or jute ropes at regular intervals. The vegetation pasture and vegetation coverage ratio were monitored using the quadrat method according to the study "Designing and Constructing Direction of Road Slope Planting" established by Korea Ministry of Land, Infrastructure and Transportin 2009 [23]. Quadrats $1 \mathrm{~m} \times 1 \mathrm{~m}$ in size were arbitrarily installed at three locations and the vegetation pasture and coverage ratio were monitored for each. The monitoring was carried out three times, i.e., at two, four and six weeks after the completion of construction. The photographs show that the vegetation flourished with time and the plants were attached and growing well on almost all slopes after six weeks. The vegetation pasture was inspected to establish which lawn grew the fastest, based on the height of the plants from the ground (Figure 17).

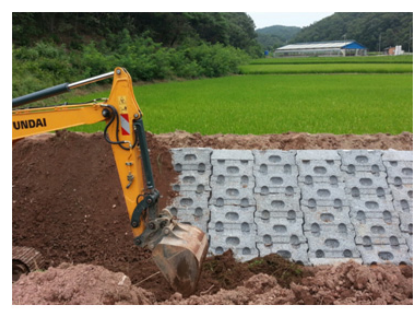

(a)

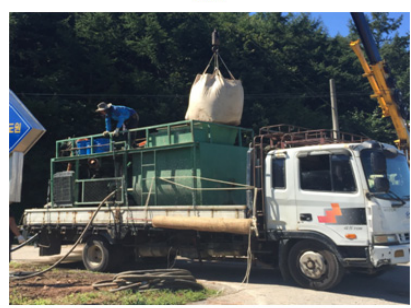

(b)

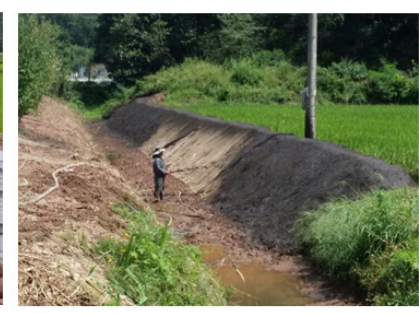

(c)

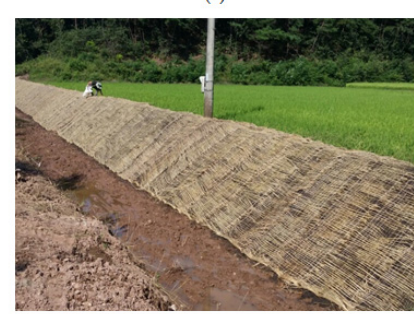

(d)

Figure 16. Photo of seeding process. (a) Soil addition; (b) Mixture of seeding materials; (c) Seeding; (d) Installation of straw mat.

Table 9. Mix proportion of seed.

\begin{tabular}{lcc}
\hline \multicolumn{1}{c}{ Type of Seed } & Mixing Amount (g) & Remark \\
\hline Mixture of three kinds of lawn grass & 4600 & Lawn grass \\
Weeping love grass & 500 & Lawn grass \\
Lythrum anceps (Koehne) Makino & 300 & Wildflower \\
Elsholtzia splenden Nakai & 150 & Wildflower \\
Plantago asiatica L. & 150 & Wildflower \\
Lotus corniculatus var. japonica Regel & 400 & Wildflower \\
Dianthus chinensis L. & 300 & Wildflower \\
Centaurea cyanus & 150 & Wildflower \\
Corepsis tinctoria & 150 & Wildflower \\
Coreopsis drummondii L. & 300 & Wildflower \\
Dendranthema boreale (Makino) Ling ex Kitam & 300 & Wildflower \\
Aster yomena & 300 & Wildflower \\
Clinopodium chinense var. parviflorum & 400 & Wildflower \\
\hline Total & 8000 & \\
\hline
\end{tabular}




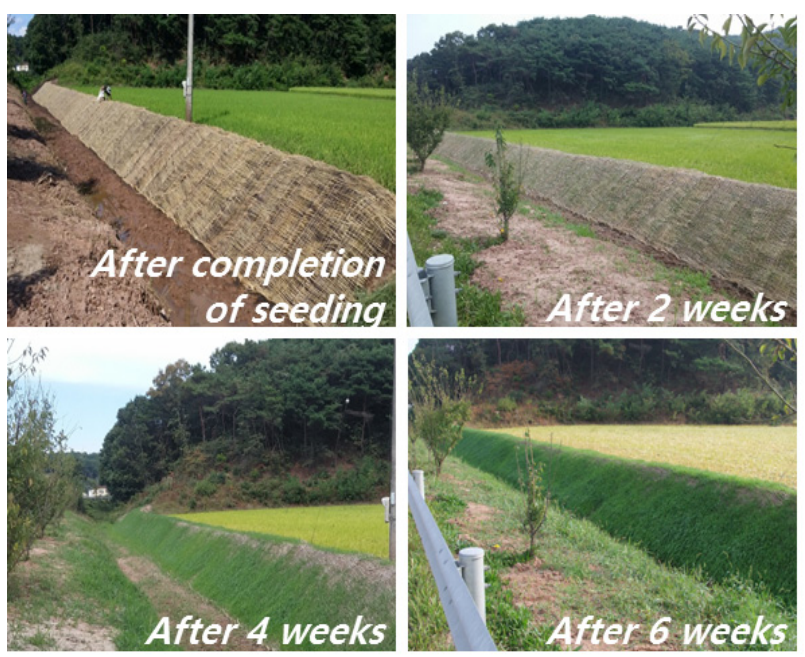

Figure 17. Photo of field application site.

Seeds began to sprout one week after planting. After two weeks, grass was 4.9-7.1 cm long in the quadrat zones. After four weeks, the length was about $20 \mathrm{~cm}$, and after six weeks, it was at least $30 \mathrm{~cm}$. Figure 18 shows the grass length for each quadrat, measured at intervals of two weeks. The coverage ratio for each quadrat is given in Figure 19. The coverage ratio after two weeks since planting was $20 \%-25 \%$ with an average of $22.7 \%$. The coverage ratio after four weeks since planting was $60 \%-68 \%$ with an average of $64.3 \%$. After six weeks, the average reached $90 \%$. The coverage ratio increased by about $30 \%$ every two weeks. Photographs of each quadrat at two-week intervals after the completion of construction are shown in Figure 20.

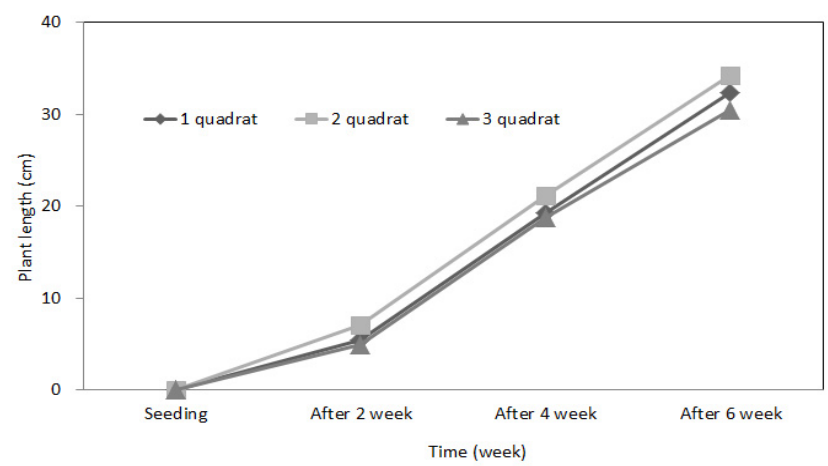

Figure 18. Graph of plant growth.

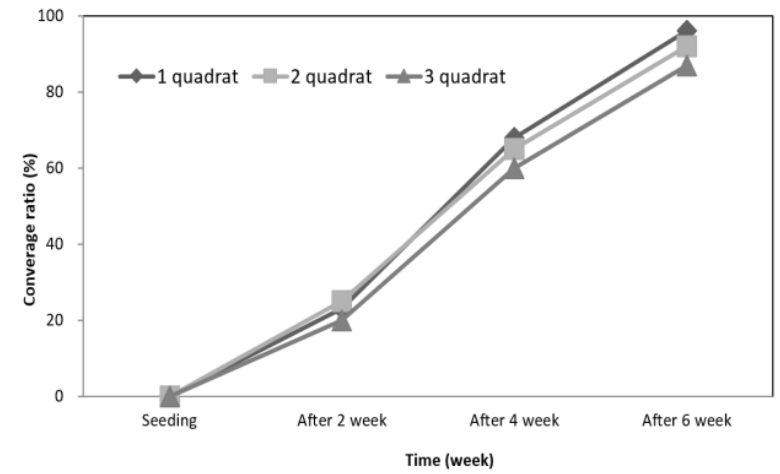

Figure 19. Graph of plants' coverage ratio. 


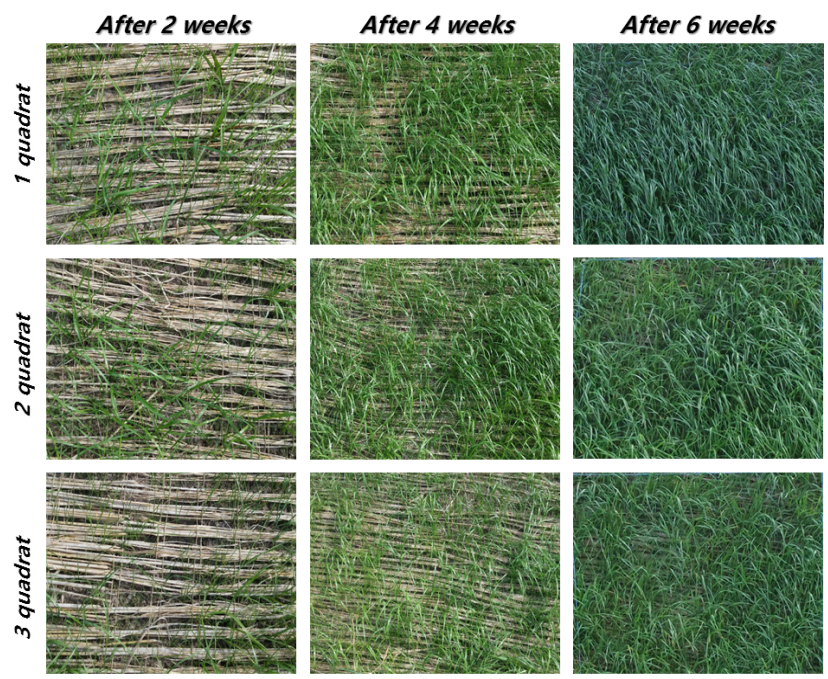

Figure 20. Photo of plants' coverage ratio research.

\section{Conclusions}

This study was conducted to evaluate the performance of porous vegetation concrete block, made from industrial byproducts in which diverse ecosystems can co-exist, to analyze its economic feasibility for in-field application, as well as its hydraulic stability, and to survey the vegetation growth after installation in the field. The results of this study are summarized as follows:

(1) Concerning the physical and mechanical properties of the porous vegetation concrete, the mixture containing latex had excellent compressive strength, void ratio and freeze-thaw resistance. Its compressive strength was $14.32 \mathrm{MPa}$, with a residual compressive strength after freezing-thawing of $87.38 \%$ and a void ratio of $27.41 \%$. These values all met the target performance. This composition was thus identified as the mixture to use for production of the porous vegetation concrete block.

(2) The economic feasibility analysis showed that using the industrial byproducts of blast furnace slag cement and blast furnace slag aggregate reduced the cost of the porous vegetation concrete.

(3) A scale model of the porous vegetation concrete was used to assess the hydraulic performance. The tractive force of this model lay between $7.0 \mathrm{~kg} / \mathrm{m}^{2}$ for fascine revetment (vegetation revetment) and $16.0 \mathrm{~kg} / \mathrm{m}^{2}$ for stone pitching (hard revetment). This tractive force indicated sufficient hydraulic stability for field installations.

(4) The utility of the installed porous vegetation concrete product was investigated. The grass length increased with time: The seeds began to sprout one week after planting and, after six weeks, the length was at least $300 \mathrm{~mm}$. The coverage ratio reached $90 \%$, on average, six weeks after planting.

Acknowledgments: This research was supported by the basic science research program through the national research foundation of Korea (NRF) founded by ministry of education (NRF-2013R1A1A4A01011776).

Author Contributions: Hwang-Hee Kim conceived and designed the experiments; Chan-Gi Park analyzed the data and wrote the paper. All authors have read and approved the final manuscript.

Conflicts of Interest: The authors declare no conflict of interest.

\section{References}

1. Kim, H.H.; Kang, S.M.; Park, J.S.; Park, S.W.; Jeon, J.H.; Lee, J.H.; Cha, S.S.; Park, C.G. Performance evaluation of porous hwang-toh concrete using blast furnace slag cement. J. Korea Soc. Argric. Eng. 2010, 52, 9-17. [CrossRef] 
2. Chindaprasirt, P.; Hatanaka, S.; Chareerat, T.; Mishima, N.; Yuasa, Y. Cement paste characteristics and porous concrete properties. Constr. Build. Mater. 2008, 22, 894-901. [CrossRef]

3. Jang, J.G.; Ahn, Y.B.; Souri, H.; Lee, H.K. A novel eco-friendly prous concree fabricated with coal ash and geopolymeric binder: Heavy metal leaching characteristics and compressive strength. Constr. Build. Mater. 2015, 79, 173-181. [CrossRef]

4. Chen, F.; Xu, Y.; Wang, C.; Mao, J. Effects of concrete content on seed germination and seedling establishment in vegetation concrete matrix in slope restoration. Ecol. Eng. 2013, 58, 99-104. [CrossRef]

5. Kim, H.H.; Kim, C.S.; Jeon, J.H.; Park, C.G. Effects on the Physical and Mechanical Properties of Porous Concrete for Plant Growth of Blast Furnace Slag, Natural Jute Fiber, and Styrene Butadiene Latex Using a Dry Mixing Manufacturing Process. Materials 2016. [CrossRef]

6. Kim, D.H.; Kim, C.S.; Park, C.G. Physical and mechanical properties of non-cement porous concrete with alkali-activator contents. J. Korea Soc. Argric. Eng. 2013, 52, 9-17. [CrossRef]

7. Kim, H.H.; Kim, C.S.; Ji, H.J.; Chan, G.P. Physical, mechanical properties and freezing and thawing resistance of non-cement porous vegetation concrete using non-sintering inorganic binder. J. Korea Soc. Argric. Eng. 2014, 56, 37-44. [CrossRef]

8. Lee, J.Y.; Park, J.S.; Park, C.G. Effect of reinforcing fiber on mechanical properties and chemical resistance of porous concrete with hwang-toh. J. Korea Soc. Civ. Eng. 2011, 55, 65-72.

9. Oh, R.O.; Kim, C.S.; Kim, H.H.; Jeon, J.H.; Kwon, W.S.; Park, C.G. Physical, mechanical and temperature properties of fiber reinforced porous green roof hwang-toh concrete. J. Korea Soc. Argric. Eng. 2013, 55, 65-72.

10. Oh, R.O.; Cha, S.S.; Park, S.Y.; Lee, H.J.; Park, S.W.; Park, C.G. Mechanical properties and water purification characteristics of natural jute fiber-reinforced non-cement alkali-activated porous vegetation blocks. Paddy Water Environ. 2014, 12, S149-S156. [CrossRef]

11. Park, S.B.; Lee, B.C.; Kim, J.H.; Yun, D.Y. Planting-ability valuation of porous concrete using industrial by-products. J. Korea Concr. Inst. 2002, 14, 623-629.

12. Park, S.B.; Lim, C.D. Concrete for planting. Mag. Korea Concr. Inst. 2000, 12, 38-42.

13. Sung, C.Y.; Kim, Y.I. Experimental study on development of plantable concrete block using rice straw ash and application for inclined plane. J. Korea Soc. Argric. Eng. 2003, 45, 107-114.

14. Youn, J.N.; Sung, C.Y.; Kim, Y.I. Physical and mechanical properties of porous concrete using waste activated carbon. J. Korea Soc. Argric. Eng. 2009, 51, 21-27. [CrossRef]

15. Advanced Construction Technology Center. Guideline of Porous Concrete River Revetment Method; ACTS: Beirut, Lebanon, 2001.

16. Mun, H.Y.; Jung, S.J.; Lim, N.K. Blast furnace slag aggregate. Mag. Korea Concr. Inst. 1997, 9, $18-22$.

17. Land \& Housing Institute. Development of Technology for the Field Application of Blast-furnace Slag Powder Concrete; Korea Land \& Housing Corporation: Seong-Nam, Korea, 2013.

18. Korea Ministry of Environment. Performance Standard for Environment Mark Certification; Permeableconcrete-EL245-2003/4/2012-36; Korea Ministry of Environment: Seoul, Korea, 2015.

19. American Society for Testing and Materials. Standard Test Method for Compressive Strength of Cylindrical Concrete Specimens; ASTM International: West Conshohocken, PA, USA, 2015.

20. American Society for Testing and Materials. Standard Test Method for Resistance of Concrete to Rapid Freezing and Thawing; ASTM C666/C666M-15; ASTM International: West Conshohocken, PA, USA, 2015.

21. Federation of Korea Concrete Industry Cooperatives. Concrete Blocks for Retaining Wall and Revetment; SPS-KCIC0001-0703; Federation of Korea Concrete Industry Cooperatives: Seoul, Korea, 2012.

22. Korean Society of Civil Engineering. Newest Riparian Engineering; Korean Society of Civil Engineering: Seoul, Korea, 2005.

23. Korea Ministry of Land, Infrastructure and Transport. Designing and Constructing Direction of Road Slope Planting; Korea Ministry of Environment: Seoul, Korea, 2009.

(C) 2016 by the authors; licensee MDPI, Basel, Switzerland. This article is an open access article distributed under the terms and conditions of the Creative Commons by Attribution (CC-BY) license (http:/ / creativecommons.org/licenses/by/4.0/). 